\title{
MITES IN THE PARENCHYMA OF JUNCUS PROCERUS IN MARSHEY WETLANDS IN THE BIO BIO REGION, CHILE
}

\section{ACAROS EN EL PARENQUIMA DE JUNCUS PROCERUS EN HUMEDALES PALUSTRES DE LA REGION DEL BIO BIO, CHILE}

\author{
Romina Villagrán-Mella, María E. Casanueva \& Luis E. Parra \\ Departamento de Zoología, Universidad de Concepción, Casilla 160-C, Concepción, Chile. Email: \\ romivime@mixmail.com; luparra@udec.cl
}

\begin{abstract}
The first record of mites in the parenchyma of Juncus procerus in marshey wetlands in the region of Bio Bio, Chile, is presented. Nine genera and families and three suborders were found. Eight species are new records for Chile and have not been previously cited as mites associated with aquatic environments. They are the following: Mesostigmata: Holoparasitus sp. and Hypoaspis sp., Prostigmata: Trombidium sp., Trombiculidae sp., Balastium sp., Cyta sp. and Eupodes sp.; and Oribatida: Pergalumna sp. Facts about habitats and known distribution are included for all found taxa.
\end{abstract}

Keywords: Acari, parenchyma, Juncacea, wetlands, Chile.

\section{RESUMEN}

Se entrega el primer registro de ácaros en el parénquima de Juncus procerus, en humedales palustres de la Región del Bío Bío, Chile. Se determinó que la acarofauna está compuesta por 9 géneros y familias y 3 subórdenes, 8 de las cuales son nuevos registros para Chile y no han sido citados previamente como ácaros asociados a ambientes acuáticos. Dentro de los Mesostigmata: Holoparasitus sp. e Hypoaspis sp.; de Prostigamata: Trombidium sp, Trombiculidae sp., Balastium sp., Cyta sp., y Eupodes sp., y dentro del suborden Oribatida: Pergalumna sp. Se incluyen datos de hábitat y distribución conocida para los taxa encontrados.

Palabras Claves: Acaros, parénquima, Juncacea, humedales, Chile.

\section{INTRODUCTION}

One way to make an effective contribution to the characterization of the biodiversity in marshey wetlands is the study of the fauna associated with emergent plants, especially among plants with longer temporary persistence. These plants constitute the most abundant vegetation in paludal wetlands (Muñoz \& Moller 1997; Moller \& Muñoz 1998). The associated fauna finds available food, shelter and space for their development within these plants which are a stable habitat for them (Jiménez 1999; Villagrán-Mella 2000).

One of the most common representatives in the paludal wetlands, between the VII to the XII Region of Chile, is Juncus procerus Mey (Fig. 1) (Baeza et al.
1997; Moller \& Muñoz 1998). It is a native species, perennial, more than one meter high, a non-terminal inflorescence, leaves that are reduced to pods at the bottom of the stem, that is erect, cylindrical and solid. The assimilating chlorophyllic parenchyma is externally surrounded by an epidermis with only one layer of cells (Barros 1953; Balslev 1996).

This parenchyma (Fig 2) has been described as the habitat for small insects that find the necessary space and food to live part- or all of their life cycle inside the rush (Villagrán-Mella 2000, 2001). Without giving specific information, Villagrán-Mella (2000) refers to the fact that mites, due to their small size and their ability to explore all types of microhabitats, also live in this habitat. 


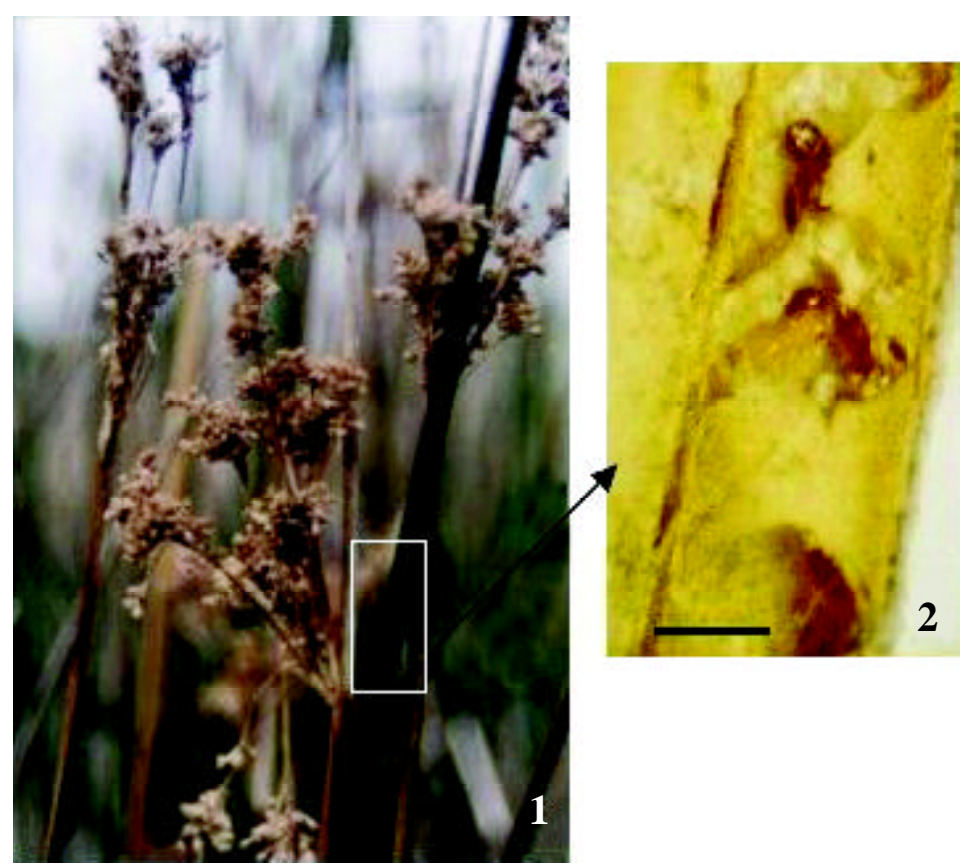

FIGUREs. 1-2. Juncus procerus. 1. General view of the stem and inflorescence. 2. Parenchyma of the stem $(0.5 \mathrm{~cm})$.

Figuras. 1-2. Juncus procerus. 1. Vista general del tallo e inflorescencia. 2. Parénquima del tallo (0.5 mm).

In Chile, the study of mites has principally focused on the taxonomy of a few groups (Casanueva 1995). Considering the accelerated deterioration of the natural communities, the diversity present in determined wild habitats should be studied. Researchs related to wetland acari are mainly on aquatic mitefauna (Cook 1988; Hammer 1962, 1970; Balogh \& Balogh 1990; Covarrubias \& Toro 1997). Information regarding mites associated with wetland plants is found in the work of Covarrubias \& Mellado (1998), which is a work on oribatida in aquatic vegetation. Regarding mites associated with the parenchyma of aquatic or emergent plants, no previous record exists in Chile, nor other references for other locations have been found.

As a contribution to the characterization of wetland fauna and to the knowledge of mites in Chile, the present work hereby delivers the first records of mites in the parenchyma of Juncus procerus from paludal wetlands in the Region of Bío Bío (VIII Region, Chile).

\section{MATERIALS AND METHODS}

The study was carried out during September, October and November of 2000 in two important emergent paludal wetlands in the Bio Bio Region (VIII Region, Chile): the areas of "Laguna Verde" (36 $47^{\circ} \mathrm{S}$; $\left.73^{\circ} 10^{\prime} \mathrm{W}\right)$ and "Laguna Price" (36 $46^{\circ}$ 'S; $\left.73^{\circ} 02^{\prime} \mathrm{W}\right)$. Both possess a similar vegetation composition where Juncus procerusis the dominant species.

Twelve stations per wetland were established, and 10 rushes of approximately $1.5 \mathrm{~m}$ high were extracted from each station.

In the laboratory, the rushes were opened lengthwise by scalpel, and checked under a stereoscopic magnifying glass in order to collect mites that inhabit the parenchyma, and which were subsequently conserved in $70 \%$ alcohol. The microscopic preparations were performed, clarifying and rinsing the material in Nesbit and mounting in Berlese.

The identification and characterization were performed, following keys and texts of Strandtmann 
(1964), Balogh (1965), Owen \& Till (1966), Mullen (1971), Cook (1976), Kethley (1978), Vainshtein et al. (1978) and Artigas \& Casanueva (1983).

\section{RESULTS}

The classification and taxonomic composition of mites that inhabiting parenchymatic tissue of Juncus procerus are presented in Table I. A total of nine morpho-species were registered in both wetlands, belonging to nine genera and families. The most diverse suborder corresponded to Prostigmata with six species.

In the following section, facts about habitat and known distribution are provided for each taxa.

TABLA I: Classification and taxonomic composition of mites that inhabiting the parenchyma of Juncus procerus, in the wetlands "Laguna Verde" and "Laguna Price".

TABLE I: Clasificación y composición taxonómica de ácaros que habitan el parénquima de Juncus procerus, en los humedales "Laguna Verde" y "Laguna Price".

\begin{tabular}{lllll}
\hline Order & Suborder & Superfamily & Family & Taxon \\
\hline Parasitiformes & Mesostigmata & Parasitoidea & Parasitidae & Holoparasitus $\mathrm{sp}$. \\
& & Dermanyssoidea & Laelapidae & Hypoaspis $\mathrm{sp}$. \\
& Prostigmata & Eupodoidea & Eupodidae & Eupodes $\mathrm{sp}$. \\
& & Bdelloidea & Bdellidae & Cyta $\mathrm{sp}$. \\
& Erythraeoidea & Erythraeidae & Balastium $\mathrm{sp}$. \\
& & Trombidioidea & Trombidiidae & Trombidium $\mathrm{sp}$. \\
& Trombidioidea & Trombiculidae & Trombiculidae sp. \\
& & Arrenuroidea & Arrenuridae & Arrenurus $\mathrm{sp}$. \\
& \multirow{2}{*}{ Oribatida } & Galumnoidea & Galumnoidae & Pergalumna $\mathrm{sp}$. \\
\hline
\end{tabular}

Holoparasitus: Free- living, common in manure, vegetarian, moss, and in animal nests; others, vertebrate parasites (Krantz 1978). The majority of the genus is cosmopolitan (Krantz 1978). There are no previous records of this genus for Chile.

Hypoaspis: Heterogeneous genus that includes parasite forms and free living ones. With representatives associated with nests of vertebrates, of arthropods and some live under insect elytrons (Krantz 1978). Evans \& Till (1966) cite species of this genus in Europe and North America. There are no previous records for Chile.

Eupodes: Predators and fungivorous, rarely associated with vertebrates. The majority of the representatives is found in humid grounds and moss in temperate, boreal and anti-boreal latitudes Genus widely distributed in the world (Krantz 1978). Womersly \& Strandtmantt (1963) cite E. wisei as a new species in the Chilean Antarctic. There are no others records for Chile.
Cyta: Of free life, from desert habitats to cold and humid vegetated habitats. Cosmopolitan (Krantz 1978). Vainshtein et al. (1978) only cites one species in South America: C. coerulipes, without further indication of record's location. There are no previous records for Chile.

Balaustium: Post-larval states predators of arthropods, aerial and terrestrial in different habitats. Cosmopolitans (Krantz 1978). There are no previous records for Chile.

Trombidium: Parasitic larva on arthropods, predominant over insects. Adults are found on plants, in the ground, in decomposing materials; they are predators (Krantz 1978; Vainshtein 1978). Cosmopolitan. Without previous record for Chile.

Trombiculiidae sp.: Parasitic larva on vertebrates, occasionally on non-vertebrates. Adults free-living in ground and terrestrial habitats (Krantz 1978). Cosmopolitan. Vainshtein et al. (1978) cites 19 
genera in the Neotropical Region, without registering further indications of location. There are no previous records for Chile.

Arrenurus: Adults of free life in rivers, lakes and paludal areas (Krantz 1978). Cook (1988) cites four species in Chile, registered in Valdivia: $A$. valdiviensis, A. solitarius, A. tenuicollis and $A$. boettgeri.

Pergalumna: Balogh \& Balogh (1990) cite 15 species in the Neotropical Region. Without previous records in Chile.

\section{DISCUSSION}

Given that there are no previous records in Chile, no references found for other geographical areas, no studies of mites associated with the parenchyma of aquatic- or emergent plants, the study of acari associated with the parenchyma of Juncusprocerus in the wetlands "Laguna Verde" and "Laguna Price" is a contribution to the characterization of the fauna of the marshey wetlands in Chile and in the world. The study of mites present in one of the most abundant emergent plants in wetlands from the VII to the XII Regions, Chile represents a significant contribution to the knowledgment of these unexplored habitats.

Furthermore, it increases our knowledge of Chilean mites by indicating the new records and probable new species. A total of nine taxa were identified. Eight have not been registered in Chile previously and they have not been cited as mites associated with wetland vegetation: Holoparasitus, Hypoaspis, Eupodes, Trombidium, Trombiculidae and Pergalumna. Only Arrenurus has been described for Chile associated with aquatic habitats. The found species probably constitutes new species which will be studied in the near future.

\section{ACKNOWLEDGMENTS}

The present paper was performed with support from the projects $\mathrm{N}^{\mathrm{o}} 2001.113 .959-1.0,200.113 .056-1.0$, 203.113.062-1.0 and Scientific Instruments 2001 of the Research Office at the University of Concepcion, Chile.

\section{REFERENCES}

Artigas, J.A. \& M.E. Casanueva. 1983. Acaros del polvo de las habitaciones de Chile. Gayana Zoología 47:1106.

Baeza, C., C. Marticorena \& R. Rodríguez. 1997. Texto guía para la identificación de la flora vascular de la Provincia de Concepción.- Proyecto de Desarrollo de la Docencia, Vicerrectoría Académica Universidad de Concepción. 364 pp.

BALOGH, J. 1965. A Synopsis of the World Oribatid (Acari) Genera. Acta Zoologica Academia Sci. Hungaricae. 11(1-2):1-99.

Balogh, J. \& P. BAlogh. 1990. Oribatid mites of the neotropical región II. Elsevier publication. New York. 333 pp.

Balslev, H. 1996. Flora Neotropica. Monografía 68: Juncaceae. Organización por la flora Neotropica. New York Botanical Garden. 167 pp.

Barros, M. 1953. Las Juncaceas de Argentina, Chile y Uruguay. Darviniana. 10(3):1-652.

Casanueva, M.E. 1995. Apuntes de acarología general.Proyecto Desarrollo de Docencia, Vicerrectoría Académica Universidad de Concepción. 139 pp.

Соок, D. 1976. New North American species of the genus Arrenurus, mostly from Florida (Acarina: Arrenuridae). Contributions to the Water Mite Fauna of North America. 11:1-58.

Cook, D. 1988. Water Mites from Chile. The American Entomological Institute. 42:1-356.

Covarrubias R. \& H. Toro. 1997. Especies de Oribatida (Acarina) asociadas a especies de plantas, en quebradas con vegetación de neblina de la Provincia de Antofagasta. Acta Entomológica Chilena. 21:1323.

Covarrubias, R. \& I. Mellado. 1998. Oribátidos de Chile (Acarina: Oribatida) II. Especies asociadas a plantas acuáticas. Acta Entomológica Chilena. 22:37- 42.

Evans, G. \&W. TILl. 1966. Studies on British Dermanyssidae (Acari: Mesostigmata). Part II. Classification Property of Institut of Acarology. Bulletin of the British Museum (Natural History) Zoology. 14(5):1-370.

HAMmER, M. 1962. Investigations on the oribatid fauna of the Andes Mountains III: Chile. Biological Skr. Dan. Vid. Selsk. 13(2):1-96.

Hammer, M. 1970. A few oribatid mites from Easter Island. Pacific Insects. 12(2):279-289.

JiMÉNEZ, M. 1999. Evaluación del estado de Conservación de las aves de humedal de la Región del Bío Bío. Habilitación profesional, Facultad de Ciencias Naturales y Oceanográficas, Universidad de Concepción \& CONAMA. $41 \mathrm{pp}$.

Kethley, J. 1978. Key Bdellidae for use in the Acarology Summer Program.- Modified from Atyeo (1960, $1963)$ and Wallace and Mahon (1972, 1976).

KrantZ, G. 1978. A Manual of Acarology.- Second Edition Departament of Entomology. Oregon State University Book Stores, Inc. Corvallis, Oregon, U.S.A. 509 pp.

Mullen, G. 1971. Water Mites of the subgenus 
Truncaturus (Arrenuridae, Arrenurus) in North America. Entomology. 17(6):1-35.

Moller, P. \& A. Muñoz. 1998. Humedales y Educación Ambiental. Editorial CEA. Valdivia, Chile. 99 pp.

Muñoz A. \& P. M oller. 1997. Conservación de humedales. Taller Bases para la Conservación de humedales en Chile.- Ediciones CEA. Valdivia, Chile. 95 pp.

Owen G. \& W. Till. 1966. Studies on the British Dermanyssidae (Acari: Mesostigmata). Part II Clasification. Bulletin of the British Museum (Natural History) Zoology. 14(5):1-370.

Sмith, I. \& D. Cook. 1991. Water Mites. Ecology and Clasification of North American Freshwater Invertebrates. Academy Press. 592 pp.

Strandtmann R. 1964. Insects of Campbell Island. Prostigmata: Eupodidae, Penthalodidae, Rhagidiidae, Nanorchestidae, Tydeidae, Ereynetidae. Pacific Insects Monograph. 15:148-165.

Vainshtein B., Volgin, V., Gilyarov, M., Krivolutskit, D., Kuznetsov, N., Lushits, I., Mitrofanov, V., Sevast'yanov, V. \& E. Sosnina. 1978. A Key to the Soil- Inhabiting Mites Trombidiformes. USSR Academy of Sciences, the Severtsov Institute of Evoluticnary Morphology and Ecology of Animals, Zoological Institute. Nauka Publishers. Moscow. $439 \mathrm{pp}$.

Villagrán-Mella, R. 2000. Composición, abundancia y distribución espacial de la entomofauna en el parénquima de Juncus procerus del humedal Laguna Verde. Unidad de Investigación para optar al grado de Licenciado en Biología, Universidad de Concepción. Concepción, Chile. 112 pp.

Villagrán-Mella, R. 2001. Comparación de la estructura del ensamble de insectos que habita en el parénquima de Juncus procerus entre los humedales Laguna Price y Laguna Verde. Tesis para optar al título de Biólogo con mención en Biodiversidad y Conservación biológica, Universidad de Concepción, Concepción, Chile. $100 \mathrm{pp}$.

Welbourn, W. 1986. Key Erithraeoidea. Modified from Southcott $(1961,1963)$. No publicada. 